\title{
Honoré de Balzac, Eugénie Grandet
}

\section{Marco Stupazzoni}

\section{(2) OpenEdition}

\section{Journals}

\section{Edizione digitale}

URL: http://journals.openedition.org/studifrancesi/4400

DOI: $10.4000 /$ studifrancesi.4400

ISSN: 2421-5856

\section{Editore}

Rosenberg \& Sellier

\section{Edizione cartacea}

Data di pubblicazione: 1 settembre 2016

Paginazione: 342

ISSN: 0039-2944

\section{Notizia bibliografica digitale}

Marco Stupazzoni, « Honoré de Balzac, Eugénie Grandet », Studi Francesi [Online], 179 (LX | II) | 2016, online dal 01 septembre 2016, consultato il 18 septembre 2020. URL : http://journals.openedition.org/ studifrancesi/4400 ; DOI : https://doi.org/10.4000/studifrancesi.4400

\section{Questo documento è stato generato automaticamente il 18 settembre 2020.}

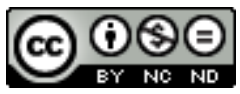

Studi Francesi è distribuita con Licenza Creative Commons Attribuzione - Non commerciale - Non opere derivate 4.0 Internazionale. 


\title{
Honoré de Balzac, Eugénie Grandet
}

\author{
Marco Stupazzoni
}

\section{NOTIZIA}

HONORÉ DE BALZAC, Eugénie Grandet, a cura di Frédéric Ieva, in appendice Prefazione e Postfazione del 1833. Orazione funebre di Victor HuGo, Milano, Feltrinelli, 2015, «Universale Economica Feltrinelli/Classici», 251 pp.

1 Per questa nuova traduzione italiana di Eugénie Grandet, curata, anche nell'apparato delle note al testo, da Frédéric Ieva, il testo di riferimento è quello stabilito da Nicole Mozet per l'edizione critica della Comédie humaine nella collezione della «Nouvelle Pléiade» di Gallimard (t. III, 1976). Tuttavia, è mantenuta la suddivisione del romanzo in sei capitoli secondo il modello dell'edizione originale del romanzo pubblicata da Mme Charles-Béchet nel 1834. In Appendice, sono riportate la traduzione della Préface e della Postface al romanzo (1833), entrambe soppresse nel 1843 (pp. 211-212; 213-214), e l'orazione funebre pronunciata da Victor Hugo alle Esequie di Balzac (21 agosto 1850), pp. 215-217.

2 Nel saggio posto alla fine del volume (Postfazione, pp. 219-230), F. Ieva ricostruisce la genesi di Eugénie Grandet, le successive fasi della pubblicazione del romanzo e la sua immediata ricezione critica: la prima menzione dell'opera da parte di Balzac, che risale alla prima metà dell'agosto del 1833 , si colloca all'inizio del tormentato «romanzo d'amore» tra lo scrittore e Mme Hanska alla quale Balzac inviò, tra l'agosto 1833 e il gennaio 1834, numerose lettere sullo stato di avanzamento nella composizione del testo.

3 Chiudono le pagine del volume un capitolo dedicato alla biografia del romanziere (Cenni biografici, pp. 233-243) e una Bibliografia essenziale, alle pp. 245-250. 